\title{
PENGARUH GREEN MARKETING TERHADAP BRAND LOYALTY YANG DIMEDIASI OLEH BRAND IMAGE
}

\author{
Gizel Gynalda Kartono ${ }^{1}$ \\ I Gde Ketut Warmika ${ }^{2}$
}

\author{
${ }^{1,2}$ Fakultas Ekonomi dan Bisnis Universitas Udayana (Unud), Bali, Indonesia \\ e-mail: gizelgynalda@gmail.com
}

\begin{abstract}
ABSTRAK
Tujuan dalam penelitian ini adalah untuk mengetahui peran brand image mernediasi pengaruh green marketing terhadap brand loyalty air minum dalam kemasan Aqua. Penelitian ini dilakukan pada 100 orang mahasiswa Fakultas Ekonomi Universitas Udayana Program Non Reguler. Penentuan sampel menggunakan metode non probality sampling. Metode pengumpulan data menggunakan kuesioner. Teknik analisis data yang digunakan adalah teknik analisis jalur (path analysis) dan uji sobel. Berdasarkan hasil penelitian yang dilakukan, ditemukan green marketing berpeugaruh positif dan signifikan terhadap brand image. green marketing berpengaruh positif dan signifikan terhadap brand loyalty, brand image berpengaruh positif dan signifikan terhadap brand loyalty dan brand image secara signifikan mampu mcmediasi pengaruh green marketing terhadap brand loyalty konsumen AMDK (Air Minum Dalam Kemasan) Aqua. Hal ini menunjukkan scmakin besar green marketing yang diperoleh dan dirasakan oleh konsumen rnaka semakin besar pula rasa brand image dan brand loyalty yang timbul dari diri pada konsumen AMDK Aqua.
\end{abstract}

Kata Kunci: green marketing, brand loyalty, brand image

\begin{abstract}
The purpose of this researchis lo know the role of brand image lo mediate the influence of green marketing on Aqua brand loyalty of drinking water. This research was conducted on 100 students of Faculty of Economies Udayana University Non-Regular Program.. Data analysis technique used is path analysis technique (path analysis) and test of sobel. Based on the results of research conducted, found that green marketing has a positive and significant impacton brand image,green marketing has a positive and significan impact on brand loyalty, brand image has a positive and significant impact on brand loyalty and brand image significantly able to mediate the influence of green marketing on consumer brand loyalty bottled drinking water Aqua. This shows the greater the green marketing gained and perceived by consumers, the greater the sense of brand image and brand loyalty that arise from the self to bottled drinking water Aqua consumers.
\end{abstract}

Keywords : green marketing, brand loyalty, brand image 
Gizel Gynalda Kartono dan I Gde Ketut Warmika, Pengaruh Green Marketing.....

\section{PENDAHULUAN}

Pada era jaman sekarang masyarakat semakin peduli tcrhadap masalah lingkungan dengan alasan bencana pencemaran lingkungan muncul dari kegiatan industri manufaktur di dunia (Chen, 2011). Upaya yang dapat dilaksanakan oleh pihak perusahaan adalah menggabungkan pendekalan ramah lingkungan terhadap pernasaran produk yang diharapkan dapat meningkatkan keunggulan kompetitif (Ginsburg dan Bloom, 2004).

Green marketing adalah pemasaran produk yang dianggap aman lingkungan, dengan demikian pemasaran ramah lingkungan menggabungkan berbagai kegiatan, termasuk modifikasi produk, perubahan proses produksi, perubahan kemasan, serta modifikasi iklan (Situmorang, 2011). Green marketing dapat didefinisikan sebagai suatu proses pemasaran produk-produk yang diasumsikan aman terhadap lingkungan (Agustin, 2015). Perusahaan harus menerapkan strategi green marketing untuk meningkatkan nilai yang dirasakan konsumen dalam produk dan mengurangi risiko produk mereka terhadap lingkungan untuk meningkatkan keunggulan kompetitif mereka (Chen, 2012).

Green marketing merupakan salah satu hal yang bisa mempengeruhi perasaan emosi serta rencana konsumen sehingga berdampak pada minat beli. Produk-produk go green muncul dengan tujuan ingin menyampaikan bahwa ketika konsumen mengkonsumsinya akan ada nilai lebih, akan ada benefit selain terpuasakan juga konsumen telah menjaga lingkungan. Sehingga dapat dikatakan green marketing merupakan konsep yang mengacu pada pemenuhan kebutuhan konsumen dengan berusaha meminimalkan dampak kerusakan terhadap lingkungan. Didukung penelitian terdahulu yang menyatakan bahwa 
green marketing berpengaruh langsung dan signifikan terhadap loyalitas pelanggan (Rejeki dkk., 2015).

Bauran pemasaran sebagai alat pemasaran yang digunakan perusahaan untuk mengejar tujuan perusahaan di pasar sasarannya (Kotler dan Amstrong, 2012:75). Bauran pemasaran ramah lingkungan (green marketing mix) merupakan pengembangan dari bauran pemasaran konvensional. Berikut indikator dari bauran green marketing: 1) Green Product. Tujuan ekologi dalam perencanaan green product adalah unruk mengurangi konsumsi sumber daya dan polusi serta menigkatkan konservasi sumber daya yang langka (Tiwari., 2011:2). 2) Green Pricing. Harga merupakan faktor penting dari bauran green marketing (Tiwari., 2011:2). Faktor yang menyebabkan harga produk ramah lingkungan lebih mahal adalah biaya yang dikeluarkan perusahaan dalam pelaksanaan green marketing lebih tinggi karena untuk memperoleh sertifikasi (Arscculeratne dan Rashad, 2014). Aqua telah memiliki sertifikasi dalam manajemen lingkungan berstandar ISO 14001:2004 Environmental Management yang diperoleh untuk manajemen pengelolaan lingkungan. 3) Green Promotion. Green promotion terdiri dari 3 jenis yakni: (1) Kampanye yang membahas hubungan antara produk, jasa dan biofisik lingkungan hidup; (2) Kampanye yang mempromosikan gaya hidup hijau dengan menyoroti produk atau jasa; (3) Kampanye yang menyajikan citra perusahaan dari tanggung jawab lingkungan. Strategi green promotion harus dimulai dari masalah bahwa konsumen belum mengetahui dan memahami konsep green marketing (Tiwari, 2011:2); 4) Green Placing. Green placing adalah ketersediaan produk memiliki 
Gizel Gynalda Kartono dan I Gde Ketut Warmika, Pengaruh Green Marketing.....

dampak yang signifikan pada pelanggan. Saluran distribusi hijau juga merupakan hal yang sangat penting dalam meminimalkan kerusakan lingkungan (Tiwari, 2011:2).

Brand image adalah proses dimana seseorang memilih, mengorganisasikan, dan mengartikan masukan informasi untuk menciptakan suatu gambaran yang berarti sehingga memiliki keyakinan atau kepercayaan atas merek tertentu (Kotler dan Keller, 2009:260). Brand image yang baik merupakan salah satu aset bagi perusahaan karena brand image mempunyai suatu dampak pada setiap persepsi konsumen, dimana masyarakat akan mempunyai kesan positif terhadap perusahaan.

Green marketing yang dilaksanakan dapat mernpengaruhi pembentukan brand image. Persepsi konsumen dari kegiatan green marketing merupakan hal yang sangat penting karena dapat mempertahankan image yang dinginkan oleh perusahaan (Haery et al., 2013). Brand image sangat penting karena dapat mempengaruhi reputasi sebuah perusahaan karena akan membantu menggambarkan kinerja perusahaan (Abd-El-Salem et al., 2013). Pendapat ahli tersebut diperkuat oleh penelitian yang menyatakan bahwa green marketing berpengaruh terhadap brand image suatu perusahaan (Romadon dkk., 2014) dan (Rambing dkk., 2015), sehingga dapat disimpulkan selain untuk memenuhi kebutuhan dan keingman konsumen, dengan konsep Green marketing dapat serta merta meningkatkan Brand image perusahaan yang jauh lebih baik yang dengan aktivitas pemasaran yang ramah lingkungan. Bila suatu produk memiliki image yang baik maka akan berdampak positif terhadap penilaian produk di 
masyarakat atau konsumen. Jika suatu produk pernah mengalami masalah yang dapat mencemarkan nama baik perusahaan maka pelanggan secara tidak langsung akan berpindah ke lain produk. Brand image adalah seperangkat asosiasi unik pikiran pelanggan mengenai apa yang menjadi hak merek dan janji tersirat dari pembuat merek (Neupane, 2015).

Citra merek (brand image) adalah persepsi yang dimiliki oleh konsumen saat pertama kali mendengar slogan yang diingat dan tertanam di benak konsumen (Kotler, 2009). Kotler juga menambahkan bahwa citra merek (brand image) adalah persepsi dan keyakinan yang dipegang oleh konsumen, seperti yang dicerminkan asosiasi suatu produk yang tertanam dalam ingatan konsumen. Jadi citra merek merupakan janji penjual untuk secara konsisten memberikan manfaat dan jasa tertentu kepada pembeli sehingga dapat membentuk persepsi di benak konsumen. Berdasarkan dari pendapat diatas, dapat disimpulkan bahwa brand image adalah citra merek yang sering berhubungan dengan persepsi konsumen terhadap produk dari merek tersebut.

Loyalitas pelanggan menujukan pada kesetiaan pelanggan pada objek tertentu, seperti merek, produk, jasa, atau toko (Arlan, 2006). Pada umumnya merek seringkali dijadikan sebagai objek loyalitas pelanggan. Loyalitas merek (Brand Loyalty) mencerminkan loyalitas pelanggan pada merek tcrtentu. Loyalitas merek merupakan suatu kondisi dimana konsumen memiliki sikap yang positif terhadap merek, memiliki komitmen terhadap merek, dan memiliki kecenderungan untuk meneruskan pembelianya di masa yang akan datang. Berdasarkan penelitian terdahulu menyatakan bahwa brand image berpengaruh 
Gizel Gynalda Kartono dan I Gde Ketut Warmika, Pengaruh Green Marketing.....

positif signifikan terhadap brand loyalty (Bastian, 2014) dan (Anwar et al., 2011). Meskipun demikian terdapat penelitian yang menunjukkan bahwa brand image tidak berpengaruh positif terhadap brand loyalty. Penelitian tersebut menyebutkan bahwa tidak ada pengaruh positif brand image terhadap brand loyalty (Upamannyu dan Mathur, 2012).

Sebagai perusahan pelopor Air Minum Dalam Kemasan (AMDK) kesetiaan terhadap merek Aqua tidak dapat begitu saja diraih, tetapi memerlukan proses panjang untuk meyakinkan konsumen bahwa Aqua merupakan merek terbaik untuk jenis AMDK. Membangun kepercayaan terhadap merek telah dilakukan oleh perusahaan Aqua sejak pertama kali mengeluarkan produk AMDK. Hal ini dibuktikan dengan adannya inovasi dan diversifikasi produk yang telah dilakukan oleh Aqua untuk selalu memberikan yang terbaik kepada konsumen. Dalam melakukan inovasi produk Aqua selalu melakukan pengembangan terhadap produk AMDK untuk memperkuat posisi pasar sebagai pemimpin pasar AMDK di Indonesia.

Salah satu perusahaan yang mengintegrasikan pemasaran lingkungan di Indonesia adalah PT Golden Missisipi dengan produk AMDK Aqua. Aksi nyata Aqua dalam menjaga lingkungan hidup di implernentasikan di mulai dari meminimalisir jejak karbon. Pengurangan jejak karbon dilakukan dengan cara audit lingkungan hijau, penghematan energi, penghematan penggunaan listrik, serta membuat konsep dimana desain kemasan yang seluruhnya dapat didaur ulang, serta menggunakan Eco Design Tool Danone untuk menghadirkan inovasi kemasan yang ramah lingkungan. Inovasi dalam kemasan yang Aqua lakukan 
dalam mengelola dampak bisnisnya dan menerapkan green marketing terhadap produknya seperti merancang ulang botol untuk mengurangi bobot kemasan seperti dalam kemasan Aqua $330 \mathrm{ml}$ saat ini bobot botol sudah dikurangi dari 12,5 gram menjadi 11 gram. Aqua juga mengubah label dari label kemasan dari PVC menjadi PP yang lebih ramah lingkungan karena bisa didaur ulang dan menghilangkan segel plastik dalam upaya mengurangi timbunan sampah. Aqua juga berkomitmen mengurangi penggunaan plastik untuk kemasan produk dengan berbagai cara, seperti tidak lagi menggunakan segel plastik memanfaatkan ulang galon lebih dari 30 persen dan seluruh kardus kemasan memakai bahan daur ulang. Selain itu, Aqua juga mempunyai pabrik hijau yang mengalokasikan sebesar 60 persen lahan dari luas pabrik untuk lahan terbuka hijau. Strategi yang digunakan oleh Aqua tersebut dikenal dengan istilah green marketing. Tujuan PT Golden Missisipi menggunakan strategi ini adalah untuk meningkatkan brand image Aqua yang kini lebih ramah lingkungan. Strategi ini diharapkan akan meningkatkan brand image yang akan berpengaruh pada brand loyalty semakin meningkatkan loyalitas masyarakat terhadap merek Aqua karena menganggap bahwa ada kebanggaan ketika mengkonsumsi Aqua yang rarnah lingkungan sehingga akan meningkatkan penjualan serta laba perusahaan.

Top Brand Index (TBI) Aqua tahun 2017 mengalami penurunan yang cukup signifikan penurunan ini tidak baik bagi Aqua dalam menghadapi persaingan AMDK di Indonesia melihat juga bahwa industri AMDK di Indonesia terus berkembang seiring dengan terus bertambahnya jumlah penduduk di Indonesia. Tahun 2013 Top Brand Index (TBI) Aqua mencapai 81.6 persen 
Gizel Gynalda Kartono dan I Gde Ketut Warmika, Pengaruh Green Marketing.....

menurun sebesar 6,4 persen menjadi 75.2 persen pada tahun 2014. Penurunan terjadi hingga tahun 2017 menjadi 73,3 persen, ini perlu diperhatikan dengan baik oleh Aqua untuk terus meningkatkan konsumennya. Berdasarkan latar belakang yang dipaparkan di atas, maka peneliti tertarik untuk melakukan penelitian mengenai pengaruh green marketing terhadap brand loyalty yang dimediasi oleh brand image pada pengguna air minum dalam kemasan Aqua.

Green marketing adalah kegiatan yang dirancang untuk menghasilkan dan memfasilitasi pertukaran yang dimaksudkan untuk mcmuaskan kebutuhan atau keinginan manusia sehingga kepuasan akan kebutuhan dan keinginan ini terjadi, dengan dampak minimal merugikan terhadap lingkungan alam (Polonsky, 2011). Green marketing dapat didefinisikan sebagai pemasaran produk yang dianggap aman lingkungan, dengan demikian pemasaran ramah lingkungan menggabungkan berbagai kegiatan termasuk modifikasi produk, perubahan proses produksi, perubahan kemasan, serta modifikasi iklan (Sirumorang, 2011).

Green marketing memiliki fungsi sebagai pengembangan produk yang proses produksi, penggunaan, dan pembuangannya tidak rnenimbulkan dampak berbahaya bagi lingkungan serta mengembangkan produk dengan memberi dampak positif bagi lingkungan (Hawkins dan Mothersbaugh, 2016:88-89). Green marketing merupakan upaya yang dilakukan oleh perusahaan untuk mendesain, mendistribusikan dan mempromosikan produk yang ramah lingkungan (Kumar, 2013). Green marketing adalah proses strategis yang melibatkan penilaian stakeholder untuk menciptakan hubungan jangka panjang terhadap pelanggan 
dengan tetap menjaga, mendukung, dan melestarikan lingkungan (Hult et al., 2012:21). Green marketing dapat dikatakan tidak sekedar menawarkan produk yang hanya ramah lingkungan, tetapi juga mencakup proses produksi, pergantian kemasan serta aktivitas modifikasi produk. Green marketing sebagai upaya stratejik yang dilakukan oleh perusahaan untuk menyediakan barangbarang dan jasa-jasa yang ramah lingkungan kepada konsumen (Grewal dan Levy, 2010). Berdasarkan dari pendapat diatas dapat disimpulkan bahwa green marketing adalah upaya dari perusahaan untuk memasarkan produknya yang termasuk ramah lingkungan baik dari proses pembuatannya hingga dari proses pemasarannya.

Brand Image menyatakan definisi merek sebagai nama, istilah, simbol, atau lambang, desain warna, gerak atau kombinasi atribut-atribut produk lainnya yang diharapkan dapat memberikan identitas dan sebagai pembeda terhadap produk pesaing. Merek adalah nama, istilah, tanda, atau lambang, atau desain, atau kombinasinya, yang dimaksudkan untuk mengidentifikasi barang atau jasa pesaing (Kotler dan Keller, 2009). Berdasarkan uraian tersebut dapat disimpulkan bahwa merek merupakan lambang atau simbol yang diberikan perusahaan terhadap produknya sebagai pembeda dengan produk lain (Tjiptono, 2008:72).

Bila suatu produk memiliki image baik, maka akan berdampak positif terhadap penilaian produk di masyarakat atau konsumen. Jika suatu produk pernah mengalami masalah yang dapat mencemarkan nama baik perusahaan, maka pelanggan secara tidak langsung akan berpindah ke lain produk. Brand image adalah seperangkat asosiasi unik di dalam pikiran pelanggan mengenai 
Gizel Gynalda Kartono dan I Gde Ketut Warmika, Pengaruh Green Marketing.....

apa yang menjadi hak merek dan janji tersirat dari pembuat merek (Neupane, 2015).

Citra merek (brand image) adalah persepsi yang dimiliki oleh konsumen saat pertama kali mendengar slogan yang diingat dan tertanam di benak konsumen (Kotler, 2009). Kotler juga menambahkan bahwa citra merek (brand image) adalah persepsi dan keyakinan yang dipegang oleh konsumen, seperti yang dicerrninkan asosiasi suatu produk yang tertanam dalam ingatan konsumen. Jadi citra merek merupakan janji penjual untuk secara konsisten memberikan manfaat dan jasa tertentu kepada pembeli sehingga dapat membentuk persepsi di benak konsumen. Berdasarkan dari pendapat diatas, dapat disimpulkan bahwa brand image adalah citra merek yang sering berhubungan dengan persepsi konsumen terhadap produk dari merek tersebut.

Loyalitas merek (brand loyalty) merupakan suatu konsep yang sangat penting dalam strategi pemasaran. Keberadaan konsumen yang loyal pada merek sangat diperlukan agar perusahaan dapat bertahan hidup (Riana, 2008). Loyalitas dapat diartikan sebagai suatu komitmen yang mendalam untuk melakukan pembelian ulang produk atau jasa yang menjadi preferensinya secara konsisten pada masa yang akan datang dengan cara membeli ulang merek yang sama meskipun ada pengaruh situasional dan usaha pemasaran yang dapat menimbulkan perilaku peralihan.

Perusahaan yang mempunyai basis pelanggan yang mempunyai loyalitas merek yang tinggi dapat mengurangi biaya pemasaran perusabaan karena biaya untuk mempertahankan pelanggan jauh lebih murah dibandingkan dengan 
mendapatkan pelanggan baru. Loyalitas merek yang tinggi dapat meningkatkan penjualan dan dapat menarik minat pelanggan baru karena mereka memiliki keyakinan bahwa membeli produk bermerek yang mempunyai resiko yang minimal. Keuntungan lain yang didapat dari loyalitas merek adalah perusahaan dapat lebih cepat untuk merespons gerakan pesaing.

Loyalitas merek (brand loyalty) merupakan suatu konsep yang sangat penting dalam strategi pemasaran. Konsurnen yang loyal pada umumnya akan melanjutkan pembelian merek tersebut walaupun dihadapkan pada berbagai alternatif merek produk pesaing yang memiliki karakteristik produk yang lebih unggul dipandang dari berbagai sudut atributnya (Jati, 2010). Loyalitas merek adalah pilihan yang dilakukan konsumen untuk membeli merek tertentu dibandingkan merek lain dalam satu kategori produk.

Loyalitas merek berbeda dengan perilaku pembelian berulang (purchasing behavior). Perilaku pembelian berulang adalah tindakan pembelian berulang pada suatu produk atau rnerek yang lebih dipengaruhi oleh faktor kebiasaan. Dalam loyalitas merek tindakan berulang terhadap merek tersebut dipengaruhi oleh kesetiaan terhadap merek (Jati, 2010). Berdasarkan dari pendapat diatas. dapat disimpulkan bahwa brand loyalty adalah keinginan dari para konsumen untuk membeli barang dari suatu merek tersebut sccara berulang- ulang.

Perusahaan yang mencrapkan strategi green marketing diharapkan dapat menciptakan brand image yang positif sehingga perusahaan mendapat dukungan dari konsumen untuk produk ramah lingkungan (Dahlstrom, 2011:6). Berdasarkan penelitian terdahulu menunjukkan bahwa variabel green marketing berpengaruh 
Gizel Gynalda Kartono dan I Gde Ketut Warmika, Pengaruh Green Marketing.....

secara positif dan signifikan terhadap variabel brand image (Aldoko, 2016), (Ramadan, 2014) dan (Wang et al., 2016). Hal ini juga sejalan dengan teori tentang salah satu tujuan green marketing yaitu green, yang memiliki tujuan untuk berkomunikasi kepada konsumen bahwa meek atau perusahaan yang peduli lingkungan hidup sehingga dapat memunculkan citra positif kepada konsumen (Grant, 2007:64).

$\mathrm{H}_{1}$ : Green Marketing berpengaruh positif dan signifikan terhadap Brand Image.

Strategi green marketing yang sukses akan mempengaruhi kepurusan konsumen terhadap produk yang perusahaan luncurkan di pasar, sehingga banyak konsumen yang mcmbeli produk ramah lingkungan dari waktu ke waktu dan lama kelamaan menjadi pelanggan yang loyal (Ottman, 2011:19). Berdasarkan penelitian terdahulu menunjukkan bahwa green marketing berpengaruh langsung dan signifikan terhadap variabel loyalitas pclanggan (Rejeki dkk., 2015) dan (Widya dan Yudi, 2017). Temuan ini juga menguatkan teori yang menyatakan bahwa banyak alasan yang mombuat konsumen untuk melakukan pembelian berulang-ulang terhadap produk yang ramah lingkungan (Ottman, 2011:16).

$\mathrm{H}_{2}$ : Green Marketing berpengaruh positif dan signifikan terhadap Brand Loyalty.

Brand Image atau citra merek merupakan persepsi konsumen tentang suatu merek sebagai refleksi dari asosiasi merek yang ada pada pikiran konsumen (Keller, 2009). Loyalitas merek adalah preferensi konsumen secara konsisten untuk melakukan pernbelian pada merek yang sama pada produk yang spesifik 
atau kategori pelayanan tertentu (Schiffman dan Kanuk, 2009). Hubungan antara citra merek dengan loyalitas merek terletak pada keinginan-keinginan dan pilihan konsumen (preference) atas suatu merek adalah merupakan sikap konsumen. Berdasarkan penelitian terdahulu menunjukkan bahwa citra merek mempunyai pengaruh yang signifikan dan positif terhadap loyalitas merek (Bastian, 2014), (Cetin el al., 2016), (Shabbir el al., 2017) dan (Seongseop Kim et al., 2018). Sesuai dengan teori yang menyatakan apabila konsumen beranggapan bahwa merek tertentu secara fisik berbeda dari merek pesaing, citra merek tersebut akan melekat secara terus menerus sehingga dapat membentuk kesetiaan terhadap merek tertentu yang disebut dengan loyalitas merek (Rangkuti, 2009).

$\mathrm{H}_{3}$ : Brand Image berpengaruh positif dan signifikan terhadap Brand Loyalty.

Hipotesis pertama dirumuskan bahwa bahwa variabel Green marketing perusahaan memiliki pengaruh yang positif terhadap Brand image. Hipotesis kedua dirumuskan bahwa Green marketing perusahaan berpengaruh positif terhadap Brand loyalty. Hipotesis ketiga dirumuskan bahwa variabel Brand image berpengaruh positif dari variabel Brand loyalty. Hasil peneliatian lain yang menunjukkan brand image berpengaruh positif dan signifikan dalam memediasi pengaruh green marketing terhadap corporate reputation (Aditya dan Sri 2017). Didukung juga oleh peneliatian yang menunjukkan brand image berpengaruh positif dan signifikan dalam memediasi pengaruh green marketing terhadap minat beli (Almuarief, 2016).

H4: Brand Image berpengaruh positif dan signifikan memediasi pengaruh Green Marketing terhadap Brand Loyalty Air Minum Dalam Keemasan. 
Gizel Gynalda Kartono dan I Gde Ketut Warmika, Pengaruh Green Marketing.....

\section{METODE PENELITIAN}

Penelitian ini dilakukan di Fakultas Ekonomi (FEB) Universitas Udayana. Alasan dipilihnya FEB Universitas Udayana Sudirman program Non Reguler karena FEB UNUD merupakan salah satu lokasi yang representatif kaum muda intelektal di Bali, karena keterbatasan waktu dan biaya penelitian maka hanya dipilih program Non Reguler saja dan asusmsi penulis bahwa sebagian besar mahasiswa FEB UNUD program Non Reguler merupakan konsumen produk AMDK. Sehingga FEB UNUD program Non Reguler sangat cocok scbagai tempat dalam melakukan penelitian.

Variabel di dalam penelitian ini terdiri dari satu variabel bebas (independent variable), satu variabel mediasi (intervening variable), serta satu variabel terikat (dependent variable). Variabel bebas tersebut adalah variabel Green marketing (X), variabel mediasi adalah Brand image (M) dan variabel terikat adalah Brand loyalty $(\mathrm{Y})$.

Populasi dari penelitian ini adalah seluruh mahasiswa Fakultas Ekonomi dan Bisnis Universitas Udayana Program Non Reguler yang berjumlah 2036 orang. Pengambilan sampel dilakukan dengan teknik purposive sampling yaitu teknik penentuan sampel dengan pertimbangan tertentu (Sugiyono, 2014:122). Teknik pengambilan sampel dengan purposive sampling atau pengambilan sampel berdasarkan karakteristik tertentu seperti: Responden yang mengtahui dan mengkonsumsi Air Minum Dalam Kemasan Aqua minimal 3 kali dalam 3 bulan terakhir. 
Diharapkan sesuai dengan karakteristik tersebut maka responden telah mempunyai pengalaman terhadap produk Aqua, memahami dan mengerti isi kuesioner sehingga dapat mengetahui dan mengukur tingkat green marketing terhadep brand loyalty dimediasi oleh brand image.

Penentuan ukuran sampel responden, untuk memperoleh hasil yang baik ukuran sampel responden yang diambil untuk mengisi kuesioner dapat ditentukan paling sedikit 5-10 kali jumlah indikator penelitian yang diteliti (Sugiyono, 2014:112). Jumlah indikator dalam kuesioner penelitian sebanyak 20 sehingga jumlah sampel adalah 5 kali jumlah pertanyaan atau sebanyak 100 . Responden yang diambil sebanyak 100 orang responden.

Metode pengumpulan data dalam penelitian ini menggunakan kuesioner. Kuesioner adalah teknik pengumpulan data yang efisien apabila peneliti tahu dengan siapa variabel akan diukur dan tahu apa yang bisa diharapkan dari responden (Sugiyono, 2014:142). Kuesioner digunakan untuk memperoleh data responden mengenai green marketing, brand image dan brand loyalty.

Analisis jalur (Path Analysis) merupakan perluasan dari analisis regresi linear berganda. Analisis jalur merupakan analisis untuk menguji pengaruh variabel mediasi dalam penelitian ini. Hasil dari uji analisis digunakan untuk membandingkan pengaruh mana yang lebih besar antara pengaruh langsung dan pengaruh tidak langsung, serta menarik suatu kesimpulan apakah dengan adanya variabel mediasi ini dapat memperkuat atau justru memperlemah pengaruh independen terhadap dependen (Ghozali, 2008). Uji Sobel merupakan alat analisis untuk menguji signifikansi hubungan tidak langsung antara variabel 
Gizel Gynalda Kartono dan I Gde Ketut Warmika, Pengaruh Green Marketing.....

independen yaitu Green Marketing (X) terhadap variabel dependen yaitu Brand Loyalty (Y) melalui variabel Brand Image (M) yang menjadi variabel mediasi.

\section{HASIL PENELITIAN DAN PEMBAHASAN}

Berdasarkan hasil penelitian menunjukkan bahwa ada tiga karakteristik dari responden yang terdiri dari jenis kelamin, program studi dan usia. Responden pada penelitian didominasi oleh responden dengan jenis kelamin lakilaki dengan persentase 58 persen atau sebanyak 58 orang dan sisanya merupakan responden perempuan sebanyak 42 orang atau 42 persen dari total keseluruhan responden. Program studi mayoritas responden adalah program studi manajemen dengan 49 persen atau 49 orang responden. Usia responden tertinggi adalah usia 20-22 tahun sebanyak 65 persen atau 65 orang responden dari total keseluruhan responden.

Perhitungan koefisien path dilakukan dengan analisis regresi melalui software SPSS 17.0 for Windows diperoleh hasil sebagai berikut:

Tabel 1.

Hasil Analisis Jalur (Regresi Substruktur 1)

\begin{tabular}{|c|c|c|c|c|c|}
\hline \multirow[b]{2}{*}{ Model } & \multicolumn{2}{|c|}{$\begin{array}{l}\text { Unstandardized } \\
\text { Coefficients }\end{array}$} & \multirow{2}{*}{$\begin{array}{r}\text { Standardized } \\
\text { Coefficients } \\
\text { Beta } \\
\end{array}$} & \multirow[b]{2}{*}{$\mathbf{T}$} & \multirow[b]{2}{*}{ Sig. } \\
\hline & B & Std. Error & & & \\
\hline (Constant) & 0.000 & 0,044 & & 0,000 & 1,000 \\
\hline Green marketing & 0,751 & 0,044 & 0,751 & 17,190 & 0,000 \\
\hline $\mathrm{R}^{2} \quad: 0,563$ & & & & & \\
\hline : 295,485 & & & & & \\
\hline$: 0,000$ & & & & & \\
\hline
\end{tabular}

Sumber: Data diolah, 2018

Berdasarkan Tabel 1 dapat dilihat bahwa koefisien diagram jalur (path) pengaruh langsung Green Marketing terhadap Brand Image adalah sebesar 0,751, maka persamaan strukturalnya adalah sebagai berikut: 


$$
\begin{aligned}
& \mathrm{Y}_{1}=\beta_{1} \mathrm{X}+\mathrm{e} \ldots \ldots \\
& \mathrm{Y}_{1}=0.751 \mathrm{X}+\mathrm{e}_{1}
\end{aligned}
$$

Berdasarkan Tabel 1 dapat dilihat bahwa koefisien diagram jalur (path) pengaruh langsung Green Marketing terhadap Brand Image adalah sebcsar 0,751 maka persarnaan strukturalnya adalah sebagai berikut :

$$
\begin{aligned}
& \mathrm{Y} 1=\beta 1 \mathrm{X}+\mathrm{e} 1 \ldots \\
& \mathrm{Y} 1=0.751 \mathrm{X}+\mathrm{e} 1
\end{aligned}
$$

Tabel 2.

Hasil Analisis Jalur (Regresi Substruktur 2)

\begin{tabular}{lcrrrr}
\hline \multicolumn{7}{c}{$\begin{array}{c}\text { Unstandardized } \\
\text { Coefficients }\end{array}$} & \multicolumn{2}{c}{$\begin{array}{c}\text { Standardized } \\
\text { Coefficients }\end{array}$} \\
Model & \multicolumn{1}{c}{ B } & \multicolumn{1}{c}{ Std. Error } & \multicolumn{1}{c}{ Beta } & \multicolumn{1}{c}{ T } & \multicolumn{1}{c}{ Sig. } \\
\hline (Constant) & 0,000 & 0,032 & & 0,000 & 1,000 \\
Green marketing & 0,388 & 0,048 & 0,388 & 8,018 & 0,000 \\
Brand image & 0,547 & 0,048 & 0,547 & 11.305 & 0,000 \\
$\mathrm{R}^{2} \quad: 0,767$ & & & & & \\
F Statistik $: 375,798$ & & & & & \\
Sig. F $\quad: 0,000$ & & & & & \\
\hline \multicolumn{4}{c}{ Sumber $:$ Data diolah, 2018} \\
\end{tabular}

Berdasarkan Tabel 2 diatas dapat dilihat koefisien diagram jalur pengaruh langsung Green Marketing terhadap Brand Loyalty sebesar 0,388 dan pengaruh langsung Brand Image terhadap Brand Loyalty adalah sebesar 0,547, maka persamaan strukturalnya adalah sebagai berikut:

$$
\begin{aligned}
& \mathrm{Y}_{2}=\beta_{2} \mathrm{X}+\beta_{3} \mathrm{Y}_{1}+\mathrm{e}_{2} \ldots \ldots \\
& \mathrm{Y}_{2}=0,388 \mathrm{X}+0,547 \mathrm{Y}_{1}+\mathrm{e}_{2}
\end{aligned}
$$

Berdasarkan model substruktur 1 dan substruktur 2, maka dapat disusun model diagram jalur akhir. Sebelum menyusun model diagram jalur akhir, terlebih dahulu dihitung nilai standar eror sebagai berikut:

$$
\mathrm{Pe}_{\mathrm{i}}=\sqrt{1-\mathrm{R}_{\mathrm{i}}^{2}}
$$




$$
\begin{aligned}
& \operatorname{Pe}_{1}=\sqrt{1-R_{1}{ }^{2}}=\sqrt{1-0,563}=0,661 \\
& \operatorname{Pe}_{2}=\sqrt{1-R_{2}{ }^{2}}=\sqrt{1-0,767}=0,483
\end{aligned}
$$

Berdasarkan perhitungan pengaruh error (Pei), didapatkan hasil pengaruh error $\left(\mathrm{Pe}_{1}\right)$ sebesar 0,661 dan pengaruh error $\left(\mathrm{Pe}_{2}\right)$ sebesar 0,483. Hasil koefisien determinasi total adalah sebagai berikut :

$$
\begin{aligned}
\mathrm{R}_{\mathrm{m}}^{2} & =1-\left(\mathrm{Pe}_{1}\right)^{2}\left(\mathrm{Pe}_{2}\right)^{2} \\
& =1-(0,661)^{2}(0,483)^{2} \\
& =1-(0,437)(0,233) \\
& =1-0,1018=0,899
\end{aligned}
$$

Nilai determinasi total sebesar 0,899 mempunyai arti bahwa sebesar 89,9\% variasi Brand Loyalty konsumen dipengaruhi oleh variasi Green Marketing dan variasi Brand Image, sedangkan sisanya sebesar 10,1\% djelaskan oleh faktor lain yang tidak dimasukkan ke dalam model.

Berdasarkan hasil analisis pengaruh Green Marketing terhadap Brand Image diperoleh nilai Sig. sebesar 0,000 dengan nilai koefisien beta 0,751. Nilai Sig. $0,000<0,05$ mengindikasikan bahwa $\mathrm{H}_{0}$ ditolak dan $\mathrm{H}_{1}$ diterima. Hasil ini mempunyai arti bahwa Green Marketing berpengaruh positif dan signifikan terhadap Brand Image.

Berdasarkan hasil analisis pengaruh Green Marketing terhadap Brand Loyalty diperoleh nilai Sig. sebesar 0,000 dengan nilai koefisien beta 0,388. Nilai Sig. $0,000<0,05$ mengindikasikan bahwa $\mathrm{H}_{0}$ ditolak dan $\mathrm{H}_{1}$ diterima. Hasil ini mempunyai arti bahwa Green Marketing berpengaruh positif dan signifikan terhadap Brand Loyalty. 
Berdasarkan hasil analisis pengaruh Brand Image terhadap Brand Loyalty diperoleh nilai Sig. sebesar 0,000 dengan nilai koefisien beta 0,547. Nilai Sig. 0,000< 0,05 mengindikasikan bahwa $\mathrm{H}_{0}$ ditolak dan $\mathrm{H}_{1}$ diterima. Hasil ini mempunyai arti bahwa Brand Image berpengaruh positif dan signifikan terhadap Brand Loyalty.

Besarnya pengaruh langsung dan pengaruh tidak langsung serta pengaruh total antar variabel. Perhitungan pengaruh antar variabel dirangkum dalam Tabel 3 sebagai berikut:

Tabel 3.

Pengaruh Langsung dan Pengaruh Tidak Langsung serta Pengaruh Total Green Marketing (X), Brand Image (M), dan Brand Loyalty (Y)

\begin{tabular}{cccc}
\hline $\begin{array}{c}\text { Pengaruh } \\
\text { Variabel }\end{array}$ & $\begin{array}{c}\text { Pengaruh } \\
\text { Langsung }\end{array}$ & $\begin{array}{c}\text { Pengaruh Tidak Langsung } \\
\text { Melalui Brand Image } \mathbf{M} \\
(\boldsymbol{\beta 3}-\boldsymbol{\beta 1})\end{array}$ & Pengaruh Total \\
\hline $\mathrm{X} \rightarrow \mathrm{M}$ & 0,751 & - & 0,751 \\
$\mathrm{X} \rightarrow \mathrm{Y}$ & 0,388 & 0,410 & 0,798 \\
$\mathrm{M} \rightarrow \mathrm{Y}$ & 0,547 & - & 0,547 \\
\hline
\end{tabular}

Sumber: Data diolah, 2018

Tabel 3 menunjukkan pengaruh langsung dan pengaruh tidak langsung serta pengaruh total Green Marketing (X) terhadap Brand Image (M) dan Brand Loyalty (Y) Air Minum Dalam Kemasan Aqua. Pengaruh total antara variabel Green Marketing (X) terhadap variabel (Y) adalah sebesar 0,751. Pengaruh total variabel Green Marketing (X) terhadap variabel Brand Loyalty (Y) adalah sebesar 0,388. Pengaruh total variabel Brand Image (M) terhadap variabel Brand Loyalty (Y) adalah sebesar 0,547. Sedangkan untuk mencari pengaruh total variabel Green Marketing (X) terhadap variabel Brand Image (M) dan variabel Brand Loyalty (Y) harus melalui pencarian pengaruh tidak langsung melalui Brand Image (M) sesuai dengan Tabel 3 diatas yang 
Gizel Gynalda Kartono dan I Gde Ketut Warmika, Pengaruh Green Marketing.....

menghasilkan pengaruh tidak langsung sebesar 0,410 dan menghasilkan pengaruh total sebesar 0,798 .

Jika mengacu pada perhitungan menggunakan statistik uji Sobel. Uji Sobel dapat dihitung dengan menggunakan aplikasi Microsoft Exel 2010. Uji Sobel dirumuskan dengan persamaan sebagai berikut:

$$
\begin{aligned}
& Z=\frac{0,388 \times 0,547}{\sqrt{\left(0,388^{2} \times 0,661^{2}\right)+\left(0,547^{2} \times 0,483^{2}\right)}} \\
& Z=\frac{0,212}{9,905}=2.1
\end{aligned}
$$

Bila nilai kalkulasi Z lebih besar dari 1,96 (dengan tingkat kepercayaan 95 persen), maka variabel mediator dinilai secara signifikan memediasi hubungan antara variabel terikat dengan variabel bebas. Berdasarkan hasil perhitungan sobel diatas, nilai $\mathrm{Z}$ adalah 2.1. Hal tersebut berarti variabel brand image secara signifikan memediasi hubungan antara variabel green marketing dan brand loyalty.

Green Marketing (X) berpengaruh terhadap Brand Image (M) Air Minum Dalam Kemasan Aqua . Hal tersebut dapat dilihat dari hasil analisis jalur yang menunjukkan bahwa Green Marketing (X) berpengaruh positif dan signifikan terhadap Brand Image (M) Air Minum Dalam Kemasan Aqua. Hal ini dilihat dari Tabel 3 hasil analisis jalur regresi substruktur 1 yang menyatakan bahwa nilai koefisien beta sebesar 0,751 yang berarti jika variabel Green Marketing dinaikkan satu satuan, maka Brand Image akan meningkan sebesar 0,751 atau dilihat dari Nilai Sig. 0,000 $<0,05$ dimana jika Nilai Sig. $<0,05$ maka $\mathrm{H}_{0}$ ditolak dan $\mathrm{H}_{1}$ 
diterima. Hal tersebut berarti bahwa adanya pengaruh Green Marketing yang positif dan signifikan terhadap Brand Image konsumen Air Minum Dalam Kemasan Aqua.

Hasil penelitian ini sesuai dengan penelitian sebelumnya yang dilakukan (Aldoko, 2016) dan (Romadon, 2014) yang menyatakan bahwa bahwa variabel green marketing berpengaruh signifikan terhadap variabel brand image. Hasil penelitian dari (Aldoko, 2016) dan (Romadon, 2014) juga diperkuat oleh penelitian (Wang et al., 2016) yang menyatakan bahwa variabel green marketing berpengaruh secara positif dan signifikan terhadap variabel brand image.

Berdasarkan hasil pengujian pengaruh Green Marketing (X) terhadap Brand Loyalty (Y) yang menunjukkan hasil koefisien beta sebesar 0,388 yang berarti apabila Green Marketing dinaikkan satu satuan, maka Brand Loyalty akam meningkat sebesar 0,388 atau dilihat dari Nilai Sig. 0,000 $<0,05$. Hal tersebut berarti terdapat pengaruh positif dan signifikan Green Marketing (X) terhadap Brand Loyalty (Y) Air Minum Dalam Kemasan Aqua.

Hasil penelitian ini sesuai dengan penelitian sebelumnya yang dilakukan (Rejeki dkk., 2015) dan yang menyatakan bahwa bahwa variabel green marketing berpengaruh signifikan terhadap variabel brand loyalty serta penelitian lain yang yang dilakukan oleh (Widya dan Yudi, 2017) yang menemukan bahwa bahwa variabel green marketing berpengaruh signifikan terhadap variabel brand loyalty.

Berdasarkan hasil analisis regresi substruktur 2 didapat hasil koefisien beta antara Brand Image (M) terhadap Brand Loyalty (Y) sebesar 0,547 yang berarti apabila Brand Image dinaikkan satu satuan, maka Brand Loyalty akan bertambah 
Gizel Gynalda Kartono dan I Gde Ketut Warmika, Pengaruh Green Marketing.....

sebanyak 0,547 atau dilihat dari Nilai Sig. 0,000 < 0,05 yang berarti $\mathrm{H}_{0}$ ditolak dan $\mathrm{H}_{1}$ diterima. Hal tersebut menunjukkan bahwa terdapat pengaruh yang positif dan signifikan antara Brand Image (M) terhadap Brand Loyalty (Y) Air Minum Dalam Kemasan Aqua.

Hasil penelitian ini tidak sesuai dengan penelitian sebelumnya yang dilakukan (Upamannyum dan Mathur, 2012) yang menyatakan bahwa tidak ada pengaruh brand image terhadap brand loyalty. Tetapi hasil penelitian dari (Bastian, 2014) dan (Anwar et al., 2011) yang menyatakan bahwa variabel brand image berpengaruh secara positif dan signifikan terhadap variabel brand loyalty.

Untuk mengetahui pengaruh Green Marketing terhadap Brand Image dan Brand Loyalty Air Minum Dalam Kemasan Aqua maka harus ditentukan dulu seberapa besar pengaruh Brand Image terhadap Brand Loyalty yang dilihat dari hasil analisis regresi substruktur 2 didapat hasil koefisien beta antara Brand image (M) terhadap Brand Loyalty (Y) sebesar 0,547 nilai Sig. 0,000 < 0,05 yang berarti $\mathrm{H}_{0}$ ditolak dan $\mathrm{H}_{1}$ diterima. Hal tersebut menunjukkan bahwa terdapat pengaruh yang positif dan signifikan antara Brand Image (M) terhadap Brand Loyalty (Y) Air Minum Dalam Kemasan Aqua. Hasil penelitian didukung oleh penelitian terdahulu menunjukan bahwa brand image berpengaruh positif dan signifikan dalam memediasi pengaruh green marketing terhadap corporate reputation (Aditya dan Sri, 2017).

Berdasarkan Tabel 3 diatas dapat dilihat bahwa terdapat pengaruh Green Marketing (X) terhadap Brand Image (M) dan Brand Loyalty (Y) dengan pengaruh total sebesar 0,798 yang sebelumnya dimediasi oleh variabel Brand 
Image (M) melalui pengaruh tidak langsung sebesar 0,410 yang berarti Green Marketing berpengaruh positif dan signifikan terhadap Brand Image dan Brand Loyalty Air Minum Dalam Kemasan Aqua.

Hasil penelitian ini memberikan sebuah implikasi kepada perusahaan Aqua mengenai pentingnya Green Maketing dan Brand Image dapat mempengaruhi Brand Loyalty Air Minum Dalam Kemasan Aqua. Green Marketing merupakan kegiatan yang dirancang untuk menghasilkan dan memfasilitasi pertukaran yang dimaksudkan untuk memuaskan kebutuhan atau keinginan manusia, sehingga Brand Image akan kebutuhan dan keinginan ini terjadi, dengan dampak minimal merugikan terhadap lingkungan alam.

Berdasarkan hasil analisis penelitian dan hasil pembahasan di atas, maka dapat ditarik simpulan sebagai berikut bahwa variabel Green Marketing (X) memiliki pengaruh yang positif dan signifikan terhadap variabel Brand Image (M) Air Minum Dalam Kemasan Aqua, hal ini berarti bahwa semakin baik Green Marketing maka akan meningkatkan Brand Image Air Minum Dalam Kemasan Aqua. Variabel Green Marketing (X) memiliki pengaruh positif dan signifikan terhadap Brand Loyalty (Y) Air Minum Dalam Kemasan Aqua, hal ini berarti bahwa semakin baik Green Marketing maka akan meningkatkan Brand Loyalty Air Minum Dalam Kemasan Aqua.

Penelitian ini telah diusahakan dan dilaksanakan sesuai dengan prosedur ilmiah, namun demikian masih memiliki keterbatasan yaitu faktor-faktor yang mempengaruhi brand loyalty dalam penelitian ini hanya terdiri dari dua indikator, yaitu green marketing, dan brand image, masih banyak faktor lain yang 
Gizel Gynalda Kartono dan I Gde Ketut Warmika, Pengaruh Green Marketing.....

mempengaruhi brand loyalty misalnya variabel kualitas produk, kepuasan konsumen, trust in brand dan lain sebagainya yang dapat dilakukan penelitian lebih lanjut kedepanya.

Penelitian hanya mcrnilih satu lokasi penelitian hanya di Fakultas Ekonomi dan Bisnis Universitas Udayana Program Non Reguler. Kedepan dapat diperluas ruang lingkup lokasi penelitiannya seperti di Kota Denpasar sehingga hasil penelitian dapat diimplementasikan secara umum.

\section{SIMPULAN DAN SARAN}

Berdasarkan hasil analisis penelitian dan hasil pembahasan di atas, maka dapat ditarik simpulan sebagai berikut bahwa variabel Green Marketing (X) memiliki pengaruh yang positif dan signifikan terhadap variabel Brand Image (M) Air Minum Dalam Kemasan Aqua, hal ini berarti bahwa semakin baik Green Marketing maka akan meningkatkan Brand Image Air Minum Dalam Kemasan Aqua.

Variabel Green Marketing (X) memiliki pengaruh positif dan signifikan terhadap Brand Loyalty (Y) Air Minum Dalam Kemasan Aqua, hal ini berarti bahwa semakin baik Green Marketing maka akan meningkatkan Brand Loyalty Air Minum Dalam Kemasan Aqua. Variabel Brand Image (M) memiliki pengaruh positif dan signiflkan terhadap Brand Loyalty (Y) Air Minum Dalam Kemasan Aqua, hal ini menunjukan bahwa Brand Image yang baik memiki pengaruh yang signifikan dalam meningkatkan Brand Loyalty Air Minum Dalam Kemasan Aqua. 
Variabel Brand Image (M) secara signifikan memediasi pengaruh Green Marketing (X) terhadap Brand Loyalty (Y) Air Minum Dalam Kemasan Aqua.

Berdasarkan simpulan tersebut, maka saran yang dapat disampaikan pada penelitian ini adalah pihak perusahaan sebaiknya lebih dan meningkatkan promosi sadar lingkungan Aqua agar menjadi lebih menarik sehingga Aqua dapat lebih menunjukkan komitmen perusahaan terhadap penggunaan green marketing. Dengan membuat promosi sadar lingkungan yang lebih menarik Aqua dapat meningkatkan citra merek di benak konsumen. Sehingga konsumen semakin antusias dalam mengkonsumsi Aqua dan loyal terhadap produk AMDK Aqua sehinggan tujuan dari pcmasaran hijau Aqua dapat terealisasi.

Bagi penelitian selanjutnya diharapkan mampu mengembangkan model pcnelitian ini dengan menambahkan variabel lain yang mempengaruhi brand loyalty konsumen selain variabel green marketing dan brand image misalnya variabel kualitas produk, kepuasan konsurnen, trust in brand dan lain sebagainya yang didukung dengan teori terbaru. Sehingga mampu menganalisis secara lebih lanjut faktor - faktor yang memiliki pengaruh terhadap brand loyalty.

\section{REFERENSI}

Abd-El-Salem, E. M., Ayman Y.S. dan Tawfik E. 2013. The Impact Of Corporate Image And Reputation On Service Quality, Customer Satisfaction And Customer Loyalty: Testing The Mediating Role. The Business \& Management Review, 3 (2), 342-360.

Aditya Saputra, I.G.P., Sri Ardani, I.G.A.K. 2017. Peran Brand Image Dalam Memediasi Pengaruh Green Marketing Terhadap Corporate Reputation. E-Jurnal Manajemen Unud, 6 (1), 87-115. 
Gizel Gynalda Kartono dan I Gde Ketut Warmika, Pengaruh Green Marketing.....

Agustin, Risna D., Kumadji, S., Yulianto, Edy. 2015. Pengaruh Green marketing Terhadap Minat Beli serta Dampaknya pada Keputusan Pembelian. Jurnal Administrasi Bisnis (JAB), 22 (2), 1-10.

Aldoko, D., Suharyono, Yuliyanto, Edy. 2016. Pengaruh Green marketing Terhadap Citra Merek Dan Dampaknya Pada Keputusan Pembelian. Jurnal Administrasi Bisnis (JAB), 40 (2), 462-678.

Almuarief . 2016. Pengaruh Green Marketing Terhadap Minat Beli Yang Dimediasi Oleh Brand Image (Studi pada Air Minum Dalam Kemasan Ades). Jurnal Manajemen, 1 (1), 382-394.

Anwar, A., Gulzar, A., Sohail, F. B. dan Akram, S. N. 2011. Impact Of Brand Image, Trust And Affect On Consumer Brand Extension Attitude: The Mediating Role Of Brand Loyalty. International Journal of Economics and Management Sciences, 5 (1), 73-79.

Arlan Tjahyadi, Rully. 2006. Brand Trust Dalam Konteks Loyalitas Merek. Peran Karakteristik Merek, Karakteristik Perusahaan dan Karakteristik Hubungan Pelanggan-Merek. Jurnal Manajemen, 6 (1), 48-61.

Arseculeratne, Dinuk dan Rashad Yazdanifard. 2014. How Green marketing Can Create a Sustainable Competitive Advantage for a Business. International Business Research, 7 (1), 130-137.

Bastian, D. A. 2014. Analisa Pengaruh Citra Merek (Brand Image) dan Kepercayaan Merek (Brand Trust) Terhadap Loyalitas Merek (Brand Loyalty) ADES PT. Ades Alfindo Putra Setia. Jurnal Manajemen Pemasaran Petra, 2 (1), 1-9.

Cetin,D.,Kuscu, A.,Ozcam, D.S. dan Erdem,Y.C. 2016. Brand Image,Satisfaction, And Brand Loyalty - How Effective Are They in the Automotive Industry Market Share. European Journal of Business and Management, 8 (7), 222-239.

Chen, Y.-S. 2011, Green Organizational Identity: Sources and Sonsequence. Management Decision, 49 (3), 384-404.

Chen, Y.-S. dan Chang, C.-H., 2012, Enhance Green Purchase Intentions The Role of Green Perceived Value, Green Perceived Risk, and Green Trust. Management Decision, 50 (3), 502-520.

Dahlstrom, Robert. 2011. Green marketing Management. Mason: South-Western Cengage Learning. 
Ghozali, Imam. 2008. Model Persamaan Struktural Konsep dan Aplikasi dengan Program SPSS. Badan Penerbit UNDIP: Semarang.

Ginsberg. J. M. dan Bloom, P. N. 2004, Choosing the Right Green marketing Strategy, MIT Sloan. Management Journal, 46 (1), 79-84.

Grant, John. 2007. The Green marketing Manifesto. West Sussex: John Wiley \& Sons, Ltd.

Grewal, D dan Levy, M. 2010. Marketing $2^{\text {nd }}$ edition. McGraw-Hill. New York.

Haery, Fariddeddin A., Morteza R. Dehaghi dan Azam Yazdani. 2013. Effect of Green marketing on Consumer Purchase Intentions With Regard to the Company's Image as a Mediator in the Retail Setting Case study: The Customers of Naghshe-e Jahan Sugar Company. International Journal of Academic Research in Business and Sosial Sciences, 3 (11), 442-452.

Hawkins, Del I. dan David L. Mothersbaugh, 2016, Consumer Behavior:Building Marketing Strategy. Thirteen Edition, McGraw-Hill International Edition.

Hult, G. Thomas M, William M. Pride dan O.C. Ferrel, 2012, Marketing, $16^{\text {th }}$ Edition, SouthWestern,Cengage Learning, International Edition.

Jati Kumoro, Sasongko. 2010. Analisis Faktor-Faktor yang Mempengaruhi Loyalitas Merek Terhadap Produk Indosat IM3. Diponogoro Journal of Management, 2 (1), 396-414.

Kotler, Philip dan Gary Armstrong. 2012. Prinsip-Prinsip Pemasaran. Edisi.13. Jilid 1. Erlangga. Jakarta.

Kotler, P dan Keller, K.L. 2009.Manajemen Pemasaran. Alih Bahasa Bob Sabran. Edisi 13, Jilid 2. Jakarta: PT Indeks.

Kumar, Awadhesh. 2013. Green Marketing: Review. Journal of Asian Research Consortium, 2 (4), 45-54.

Neupane, Ramesh. 2015. The Effects Of Brand Image On Customer Satisfaction And Loyalty Intention In Retail Super Market Chain Uk, International Journal of Social Sciences and Management, 2 (1), 9-26.

Ottman, Jacquelyn A. 2011. The New Rules of Green marketing. England: Greenleaf Publising, Sheffield.

Polonsky, MJ. 2011. Transformative Green Marketing: Impediments and Oportunities. Journal of Business Research, 64 (12), 1311-1319. 
Gizel Gynalda Kartono dan I Gde Ketut Warmika, Pengaruh Green Marketing.....

Rambing, P.R., Tumbel, A.L., Hendra, N. 2015. Pengaruh Strategi Green Marketing Terhadap Keputusan Pembelian Dengan Citra Merek Sebagai Variabel Intervening Pada Produk Air Minum Dalam Kemasan, Aqua Di Manado. Jurnal EMBA, 3 (2), 235-245.

Rangkuti, Freddy. 2009. Strategi Promosi yang Kreatif dan Analisis Kasus. Integrated Marketing Communication. Jakarta : PT Gramedia Pustaka Utama.

Rejeki, Denik S., Fauzi, A.D.H. dan Yulianto, Edy. 2015. Pengaruh Green marketing Pada Keputusan Pembelian Dan Implikasinya Terhadap Loyalitas Pelanggan. Jurnal Administrasi Bisnis (JAB). 26 (1), 268-287.

Riana, Gede. 2008. Pengaruh Trust In A Brand Terhadap Brand Loyalty Pada Konsumen Air Minum Aqua Di Kota Denpasar. Jurnal Manajemen Universitas Udayana Denpasar, 1 (1), 143-157.

Romadon, Yusuf, Kumadji, Srikandi dan Abdillah, Yusri., 2014, Pengaruh Green Marketing Terhadap Brand Image Dan Struktur Keputusan Pembelian. Jurnal Administrasi Bisnis (JAB), 15 (1), 278-295.

Schiffman, L.G dan L.L. Kanuk. 2009. Customer Behavior, New Jersey : Prentice - Hall International, Inc.

Seongseop Kim, Ja Young Choe James F. Petrick. 2018. The Effect Of Celebrity On Brand Awareness, Perceived Quality, Brand Image, Brand Loyalty, And Destination Attachment To A Literary Festival. Journal Of Destination Marketing \& Management, 9 (1), 320-329.

Shabbir, M. Qasim, Khan, Ansar Ali dan Khan, Saba Rasheed .2017. Brand Loyalty, Brand Image and Brand Equity: The Mediating Role of Brand Awareness. International Journal of Innovation and Applied Studies, 19 (2), 416-423.

Situmorang, R. James. 2011. Pemasaran Hijau yang Semakin Menjadi Kebutuhan dalam Dunia Bisnis. Jurnal Administrasi Bisnis, 7 (2), 131142.

Sugiyono. 2014. Metode Penelitian Pendidikan Pendekatan Kualitatif, Kuantitatif, dan R\&D. Bandung: Alfabeta

Tiwari, Sandeep, Durgesh Mani Tripati, Upsana Srivasta dan PK.Yadav. 2011 Green Marketing - Emerging Dimension. Journal of Business Excellence, 4 (1), 9-11.

Tjiptono, Fandy. 2008. Strategi Pemasaran. Edisi ke 3. Yogyakarta: Andi. 
Upamannyu, Nischay K. dan Mathur, Garima. 2012. Effect of Brand Trust, Brand Affect and Brand Image on Customer Brand Loyalty and Consumer Brand Extension Attitude In Framing Sector. PRiMa: Practices and Research in Marketing, 3 (2), 112-129.

Wang, Ya-Hui, Chen, Ssu-Ting dan Chen, Nai-Ning., 2016, An Empirical Study of the Effect of Green marketing on Purchase Intention - Evidence from Green Restaurant. Advances in Management \& Applied Economics , 6 (4), 1-14.

Widya Sari, I.G.A., Yudi Setiawan, Putu. 2017. Pengaruh Green Marketing dan Packaging Terhadap Brand Image dan Loyalitas Pelanggan Pada Konsumen Starbucks Coffee. E-Jurnal Manajemen Unud, 6 (7), 3820-2849. 